\title{
New Scolecitrichidae (Copepoda: Calanoida) from deep Antarctic waters
}

\section{Новый виА и род семейства Scolecitrichidae (Copepoda: Calanoida) из глубоководной Антарктики}

\author{
Elena L. Markhaseva ${ }^{1}$, Knud Schulz ${ }^{2} \&$ Jasmin Renz ${ }^{2}$

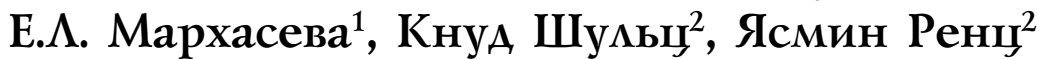

\begin{abstract}
${ }^{1}$ Russian Academy of Sciences, Zoological Institute; Universitetskaya nab. 1, 199034 St. Petersburg Russia. E-mail: copepoda@zin.ru Зоологический институт РАН, Университетская наб., 1, Санкт-Петербург 199034 Россия.

${ }^{2}$ DZMB-Senckenberg, Biozentrum Grindel \& Zoologisches Museum, Martin-Luther-King-Platz 3, D-20146 Hamburg Germany. E-mail: kschulz@zoologie.uni-hamburg.de; Jasmin.Renz@senckenberg.de
\end{abstract}

KEY WORDS: Copepoda, Calanoida, new genus, new species, benthopelagic, Antarctic deep sea.

КЛЮЧЕВЫЕ СЛОВА: Copepoda, Calanoida, новый род, новый вид, бентопелагический, глубоководная Антарктика.

ABSTRACT. A new clausocalanoidean benthopelagic genus and species, Diaiscolecithrix andeep, with sensory setae on maxilla and maxilliped is described from the Southern Ocean deep waters close to the sea bed and placed in the clausocalanoidean family Scolecitrichidae. The new genus is well defined from all scolecitrichid genera by a well developed oral conelike structure, a single seta on the distal praecoxal endite of the maxilla, an elongate and slender gnathobase blade of the mandible and details of setation of the oral parts. Diaiscolecithrix gen.n. shares with Scolecitrichidae the setation of antenna and mandible palp, 3 worm-like and 5 brush-like sensory setae on the maxilla endopod, and a setal sequence of $1,2,1$ on the praecoxal endites of the maxilliped syncoxa. Including Macandrewella Scott, 1909, Scolecitrichopsis Vyshkvartzeva, 2000, and Omorius Markhaseva \& Ferrari, 2005 , that all share this combination of characters, the new genus is the fourth representative of Scolecitrichidae found in the benthic boundary layer.

РЕЗЮМЕ. Из придонных глубоководных слоев Южного Океана описан новый бентопелагический род и вид надсемейства Clausocalanoidea Diaiscolecithrix andeep с сенсорными щетинками на максилле и максиллипеде, который помещен в семейство Scolecitrichidae. Новый род хорошо отличим от остальных представителей Scolecitrichidae хорошо развитой структурой типа ротового конуса, наличием одной щетинки на дистальном прекоксальном эндите максиллы, удлиненной и изящной гнатобазой мандибулы и некоторыми другми деталями вооружения ротовых частей. В то же время у Diaiscolecithrix gen.n. эндоподит максиллы с 3 червевидными и 5 кисточковидными сенсорными щетинками и синкокса максиллипеды с последовательностью щетинок на прекоксальных эндитах -
1, 2, 1, а антенна и мандибулярная пальпа вооружены как у большинства Scolecitrichidae. Включая $M a-$ candrewella Scott, 1909, Scolecitrichopsis Vyshkvartzeva, 2000, и Omorius Markhaseva \& Ferrari, 2005, которые также характеризуются этой комбинацией признаков, новый род стал четвертым представителем Scolecitrichidae найденным в придонном слое вод.

\section{Introduction}

Records of representatives of the predominantly pelagic calanoid family Scolecitrichidae in samples collected in the benthopelagic waters of the World Oceans are rare up to now and only few scolecitrichid species of the genera Macandrewella, Scolecitrichopsis and Omorius have been attributed to the near-bottom zone [Grice \& Hulsemann, 1970; Ohtsuka et al., 2002; Schulz, 2005; Markhaseva \& Ferrari, 2005; Markhaseva \& Schulz, 2007]. Therefore, findings of a new scolecitrichid genus and species in the Southern Ocean above the sea bed are of particular interest both in taxonomic and ecological view.

In this paper a new genus Diaiscolecithrix is established including one new species Diaiscolecithrix andeep based on the adult female and female copepodite V sorted from ANDEEP-SYSTCO samples. A second species that was found in the collections obtained during ANDEEP-III expedition has not been named because of its poor condition.

The new genus is placed in Scolecitrichidae sensu Markhaseva \& Ferrari [2005].

\section{Material and methods}

Benthopelagic calanoid copepods were collected by RV Polarstern during ANDEEP-III and ANDEEP- 
SYSTCO expeditions (in 2005 and 2008 respectively) to the South of $52^{\circ} \mathrm{S}$ in the Southern Ocean at abyssal depths of 2152 to $3820 \mathrm{~m}$ using an epibenthic sledge with a mesh size of $0.50 \mathrm{~mm}$ [Brenke, 2005]. Details of the cruises were given by Brandt \& Hilbig [2004] and Brandt et al. [2007]. Collections were made in the benthic boundary layer ca. $0.1-1.3 \mathrm{~m}$ above the bottom.

Specimens were initially fixed in $96 \%$ ethanol and later stained by adding a solution of chlorazol black $\mathrm{E}$ dissolved in $70 \%$ ethanol $/ 30 \%$ water. Oral parts and swimming legs were dissected, mounted in glycerine and figures were drawn using a camera lucida.

The following abbreviations are used in the descriptions: P1-P4, swimming legs 1-4; scl- sclerotized (setae), w-worm-like (sensory setae), br-brush-like (sensory setae). Free segments of the antennule are designated by Arabic numerals, ancestral segments by Roman numerals. One seta and one aesthetask on a segment of the antennule are designated: $1 \mathrm{~s}+1 \mathrm{ae}$.

The type specimen is deposited at the Zoological Museum Hamburg (ZMH), University of Hamburg.

\section{Taxonomy}

Family Scolecitrichidae Giesbrecht, 1893

\section{Genus Diaiscolecithrix gen.n.}

Type species Diaiscolecithrix andeep sp.n., here designated.

DIAGNOSIS. Female. Scolecitrichidae. Cephalosome and pediger 1 partly fused, pedigers 4 and 5 separate. Posterior corners of prosome as short triangular lobes pointed distally. Rostrum present as a plate with fimanets. Upper and lower lips are well developed and form circular oral cone-like structure. Urosome of 4 somites; genital double-somite symmetrical. Antennule of 24 articulated segments, first segment with 3 setae. Antenna exopod segment 1 without setae, endopod segment 1 with 1 seta, exopod nearly 1.5 times as long as endopod. Mandibular gnathobase elongate and slender with 2 acute spine-like teeth distally; basis with 2 setae, endopod segment 1 without setae; segment 2 with 9 setae; exopod 5-segmented with 1, 1, 1, 1, and 2 setae. Maxillule praecoxal arthrite with 7 setae; coxal endite, proximal basal endite and distal basal endite with 2 setae each, endopod segments fused with 4-5 setae including at least one sensory; exopod with 7 setae; coxal epipodite with 8 setae.

Maxilla praecoxa with outer hump; proximal praecoxal endite with 3 setae; distal praecoxal endite with 1 seta; coxal endites with 2 setae each; proximal basal endite with 4 setae; distal basal endite plus endopod with 8 setae: 3 long worm-like and 5 brush-like sensory setae. Maxilliped syncoxa with 1, 2, and 1 setae on proximal praecoxal, middle and distal praecoxal endite respectively; coxal endite with 3 setae; basis with 3 medial setae; Endopod segments 2 to 5 with 4, 3, 3+1, and 4 setae. Segmentation and setation of P1-P4 typical for Clausocalanoidea. P5 present, 2-segmented and lacking spines on both segments.
Male unknown.

ETYMOLOGY. The generic name is a combination of Diaixis Sars, 1902 and Scolecithrix Brady, 1883 and refers to the similarity of morphological characters of the new genus with regard to Diaixis and Scolecithrix. Gender masculine.

\section{Diaiscolecithrix andeep sp.n.}

Figs 1A-H, 2, 3, 4A-C, 5.

MATERIAL. Holotype, adult female, partly dissected, body length $1.51 \mathrm{~mm}$ (ZMH K-42379). Southern Ocean, 64²9'S $02^{\circ} 53^{\prime} \mathrm{E}$, ANDEEP-SYSTCO expedition, station 39-17; 04 January 2008 , above the seabed at a depth of $2152 \mathrm{~m}$.

ADDITIONAL MATERIAL. CV female, Southern Ocean, $52^{\circ} 02^{\prime} \mathrm{S} 00^{\circ} 00^{\prime} \mathrm{E}$, ANDEEP-SYSTCO expedition, station $85-8 ; 27$ January 2008, above the seabed at a depth of $2987 \mathrm{~m}$.

DESCRIPTION. Adult female, total length 1.51 $\mathrm{mm}$; prosome 3.9 times longer than urosome. Genital double-somite with slender spermathecae extending dorsally. Rostrum a well developed plate with 2 filaments (Fig. 1C-D). Cephalosome and pediger 1 and pedigers 4 and 5 separate; posterior corners of prosome as short triangular lobes with small distal points in lateral view (Fig. 1A-B, F-H). Upper and lower lips well developed to form circular oral cone-like structure, with distal parts supplied by edging of densely arranged setules (Fig. 1E, J). Caudal rami with 4 terminal plus 1 ventral and 1 dorsal setae (Fig. $1 \mathrm{H})$.

Antennules (Fig. 2A) slightly shorter than prosome; of 24 free segments, armature as follows: I-3s, II-IV$6 \mathrm{~s}+1 \mathrm{ae}, \mathrm{V}-2+1 \mathrm{ae}, \mathrm{VI}-2 \mathrm{~s}, \mathrm{VII}-2 \mathrm{~s}+1 \mathrm{ae}, \mathrm{VIII}-2 \mathrm{~s}$, IX-2s $+1 \mathrm{ae}, \mathrm{X}-\mathrm{XI}-4 \mathrm{~s}+1 \mathrm{ae}, \mathrm{XII}$ without seta, XIII$1 \mathrm{~s}, \mathrm{XIV}-2 \mathrm{~s}+1 \mathrm{ae}, \mathrm{XV}-1 \mathrm{~s}, \mathrm{XVI}-2 \mathrm{~s}+1$ ae, XVII-1s, XVIII-2s, XIX-1s, XX-2s, XXI-1s + 1ae, XXII to XXIII-1s each, XXIV to XXVI-2s each, XXVII-XXVIII-4s + 1ae.

Antenna (Fig. 2B), coxa with 1 small seta, basis with 2 setae, exopod 7-segmented with $0,(0-0-0-1)$, $1,1,1,1$ and 3 setae; exopod nearly 1.5 times as long as endopod; first endopodal segment with 1 seta, second with 8 and 6 setae.

Mandible (Fig. 3A), gnathobase elongate and slender with 2 strong, acutely pointed and 3 small teeth distally; basis with 2 setae, exopod 5-segmented, nearly as long as endopod, with 1, 1, 1, 1, and 2 setae; endopod segment 1 without setae, segment 2 with 9 setae.

Maxillule (Fig. 3B-C), praecoxal arthrite with 7 terminal setae; coxal endite, proximal basal and distal basal endite, each with 2 setae, latter with both sensory in distal parts; endopod segments fused with 5 setae including 3 sensory; exopod with 7 setae; coxal epipodite with 8 setae.

Maxilla (Fig. 4A, C), praecoxa with outer hump; proximal praecoxal endite with 3 setae; distal praecoxal endite with 1 seta; coxal endites with 1 sclerotized plus 1 worm-like sensory setae each; proximal basal endite with 4 setae, of these 2 thin sclerotized and 2 worm-like sensory setae; distal basal endite plus endopod with 8 setae: 3 long worm-like sensory and 5 brush-like sensory setae of different morphology: 3 


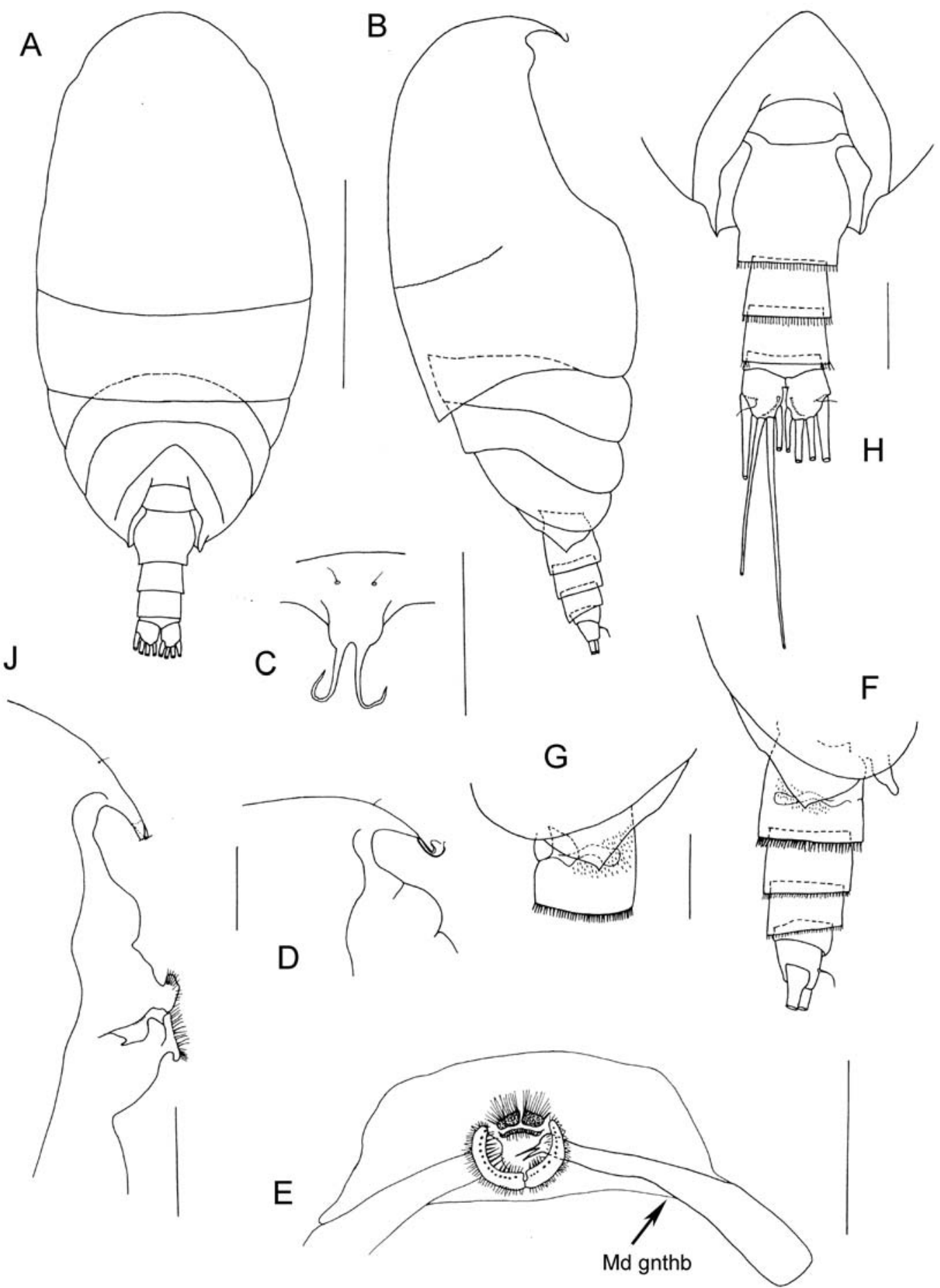

Fig. 1. Diaiscolecithrix andeep gen. et sp.n., female, holotype (A-H) and Diaiscolecithrix sp. (J): A - habitus, dorsal view; B habitus, lateral view; $\mathrm{C}$ - rostrum, ventral view; $\mathrm{D}$ - rostrum, lateral view; E — oral cone-like structure, distal part, ventral view; F posterior prosome and urosome, lateral view; $\mathrm{G}$ - posterior prosome and genital double-somite, lateral view; $\mathrm{H}$ - posterior prosome and urosome, dorsal view; J - cephalosome and oral cone-like structure, anterior lateral view, filaments of rostrum broken. Scales bars for A$\mathrm{B}-0.5 \mathrm{~mm}$, remaining figures $-0.1 \mathrm{~mm}$.

Pис. 1. Diaiscolecithrix andeep gen. et sp.n., самка, голотип (A-H) и Diaiscolecithrix sp. (J): А - общий вид со спины; В общий вид сбоку; С — рострум с брюшной стороны; D - рострум сбоку; Е — дистальная часть структуры типа ротового конуса с брюшной стороны; $\mathrm{F}$ - задняя часть просомы и уросомы сбоку; $\mathrm{G}$ - задняя часть просомы и генитальный сомит сбоку; $\mathrm{H}-$ задняя часть просомы и уросома со спины; J - передняя часть цефалосомы со структурой типа ротового конуса сбоку, филаметы рострума оборваны. Масштаб для А-B - 0,5 мм, для остальных рисунков - 0,1 мм. 


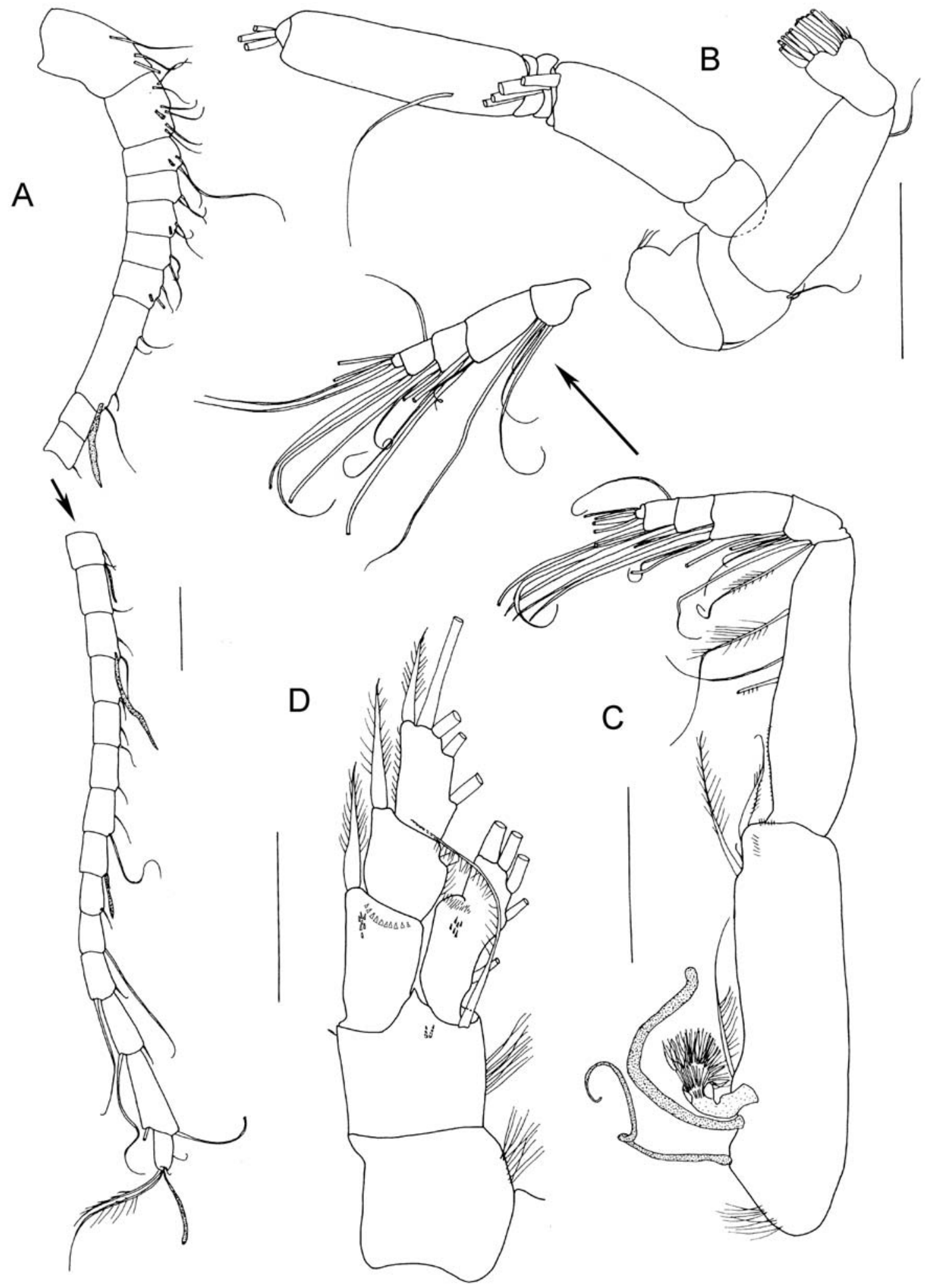

Fig. 2. Diaiscolecithrix andeep gen. et sp.n., female, holotype: A - antennule; B - antenna; C - maxilliped; D - P1 (anterior). Scale bars $0.1 \mathrm{~mm}$.

Pис. 2. Diaiscolecithrix andeep gen. et sp.n., самка, голотип: А — антеннула; В — антенна; C - максиллипеда; D - P1 (передняя поверхность). Масштаб 0,1 мм. 


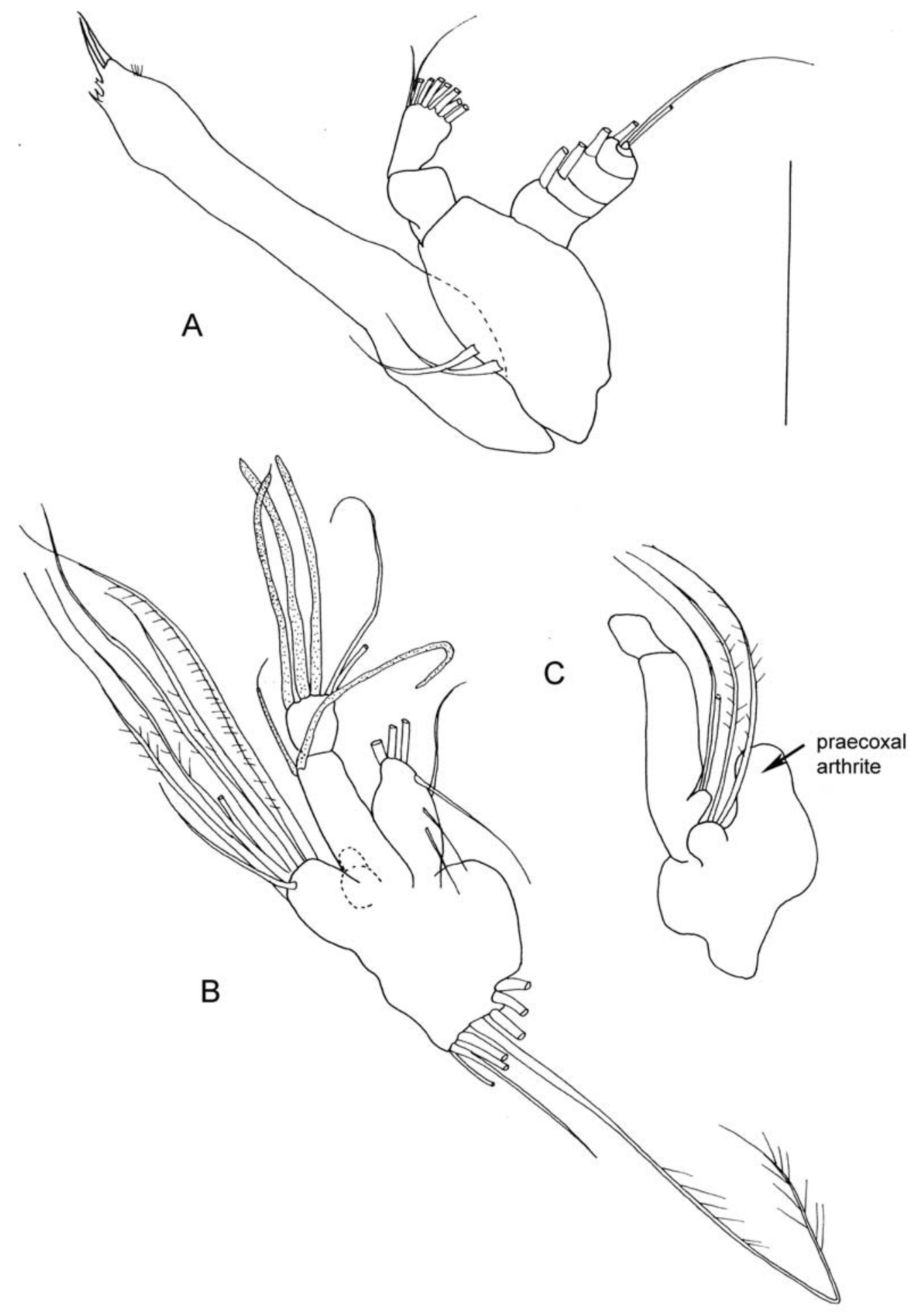

Fig. 3. Diaiscolecithrix andeep gen. et sp.n., female, holotype: A - mandible; B - maxillulle, setae on coxal and proximal basal endite are not given; $\mathrm{C}-$ maxillulle, setae on praecoxal arthrite, distal basal endite, endopod, exopod and epipodite are not given. Scale bars $0.1 \mathrm{~mm}$.

Рис. 3. Diaiscolecithrix andeep gen. et sp.n., самка, голотип: А - мандибула; В - максиллула, щетинки коксального и проксимального базального эндитов не изображены; C - максиллула, щетинки прекоксального артрита, дистального базального эндита, эндо-, экзо- и эпиподита не изображены. Масштаб 0,1 мм. 
thick with well developed brushes (shown by arrow in Fig.4 A) and 2 longer setae with small and weakly developed brushes apically. CV female with brush-like setae not fully developed.

Maxilliped (Fig. 2C), syncoxa with 1 worm-like sensory seta on proximal praecoxal endite; 2 sensory setae on middle endite, 1 worm-like and 1 brush-like, and 1 sclerotized seta on distal praecoxal endite; coxal endite with 3 setae and row of spinules along distal and medial edge; subterminal seta is very small compared to proximal and terminal setae; basis with 3 medial setae. Endopod 6-segmented, with 2, 4, 3, 3+1, and 4 setae.

P1 (Fig. 2D), coxa without seta; basis with very small distolateral seta, medial distal seta smoothly curved; two small denticles present on posterior surface; endopod 1-segmented bearing lateral lobe ornamented with denticles and patch of denticles on anterior surface. Exopod segment 1 with patch of spinules on anterior surface and semicircular row of spinules on posterior surface; exopod segments 1,2 , and 3 with 1 lateral spine each densely pubescent; spine of exopod segment 1 not reaching mid-length of second spine, spine of exopod segment 2 extending to mid-length of third spine.

P2 and P3 with finely serrate and comparatively elongate terminal spine on exopod segment 3. P2 (Fig. $5 \mathrm{~A}$ ), coxa with medial seta; basis without seta; endopod 2-segmented; exopod 3-segmented; posterior surface of coxa and basis with patches of tiny spinules; both anterior and posterior surfaces of endo- and exopod spinulated with posterior surface bearing denser spinules.

P3 (Fig. 5B), coxa with medial seta, basis without seta; both endopod and exopod 3-segmented, surface spinulation as for P2. Terminal spine of exopod segment 3 slender and nearly as long as endopod.

P4 (Fig. 5C), coxa with medial seta, basis without seta; endopod 3-segmented, exopod segments 2 and 3 broken. Posterior and anterior surface spinulation of coxa, basis and rami more densely ornamented than in P2-P3.

P5 (Fig. 4B), 2-segmented, posteriorly with surface spinulation, terminal segment slightly longer than coxa, with terminal part narrowing and rounded distally and lacking spines.

ETYMOLOGY. The species epithet is derived from the name ANDEEP and refers to the expedition in which the species was obtained.

\section{Diaiscolecithrix sp.}

Figs 1J, 4D.

MATERIAL. Adult female in poor condition, $1.50 \mathrm{~mm}$; Southern Ocean, 62 $32^{\circ} \mathrm{S} 64^{\circ} 39^{\prime} \mathrm{W}$, ANDEEP-III, station 154-9; 30 March 2005, above the seabed at a depth of 3820-3744 m.

General habitus $(1 \mathrm{~J})$, segmentation and setation of oral parts and swimming legs similar to the type species. It differs in the following characters: i) maxillule with 2 setae on distal basal endite, but setae are not sensory (vs. of sensory type in type species); ii) maxillule endopod with 4 setae including 1 sensory (vs. 5 setae of which 3 are sensory in congener), iii) coxal epipodite with 7 setae (vs. 8 setae in D. andeep), and iv) P5 of different shape (Fig. 4D). Diaiscolecithrix sp. shares the same sequence $(1,2,1)$ and composition of setae on the praecoxal endites of maxilliped syncoxa.

REMARKS. Diaiscolecithrix gen.n. appears to be the only genus to possess a well developed oral conelike structure among clausocalanoidean families that bear sensory setae on maxilla and maxilliped (viz. Diaixidae, Tharybidae, Scolecitrichidae, Parkiidae, Phaennidae, and Rostrocalanidae). The new genus is also distinct in that it has a single seta on the maxilla distal praecoxal endite (vs. 3, rarely 2, setae in remaining scolecitrichids); both characters are apomorphies for the genus.

Diaiscolecithrix shares with other scolecitrichids the setation of antenna and mandible palp, number and composition of sensory setae on maxilla endopod and distal basal endite ( 3 worm-like and 5 brush-like sensory setae) as well as the number and sequence $(1,2,1)$ of setae on the praecoxal endites of maxilliped.

Diaiscolecithrix deviates from all scolecitrichid genera in a very elongate and slender gnathobase blade of mandible and shares this character only with some species of the genus Diaixis (family Diaixidae). However the cutting edge of the gnathobase is not of the chewing type, but the two distal acute spines seem appropriate for piercing into the tissue of prey to facilitate a sucking feeding mode.

Diaiscolecithrix can be distinguished from all Scolecitrichidae by: i) maxillule praecoxal arthrite with 7 terminal elements (vs. 9 terminal elements in Scolecitrichidae, but 7 elements in Heteramalla Sars, 1907, a genus of unclear affiliation); ii) maxillule distal basal endite with 2 setae (vs. usually $4-5$ or rarely 3 or 6 setae in other Scolecitrichidae, but 2 setae as well in several genera of Tharybidae and Diaixidae); iii) maxillule distal basal endite and endopod with 2 and 3 worm-like sensory setae respectively (vs. these setae always sclerotized in Scolecitrichidae, but it shares the presence of 2 worm-like sensory setae with Diaixis asymmetrica Grice \& Hulsemann, 1970); iv) maxilla coxal endites with 2 setal elements each (vs. 3 setae in other scolecitrichids, this character shared with Kyphocalanus Markhaseva \& Schulz, 2009 of the family Kyphocalanidae); v) maxilla praecoxa with outer hump (vs. hump absent in remaining Scolecitrichidae, but this character also typical for D. asymmetrica); and vi) medial praecoxal endite of maxilliped with worm-like and brush-like setae (vs. brush-like seta present only on distal praecoxal endite in other scolecitrichids, except for Omorius and Archescolecithrix Vyshkvartzeva, 1989 which totally lack brush-like sensory setae on maxilliped syncoxa).

As mentioned above, the new species shares with the only known female specimen of Diaixis asymmetri$c a$ an elongate gnathobase blade of mandible and de- 


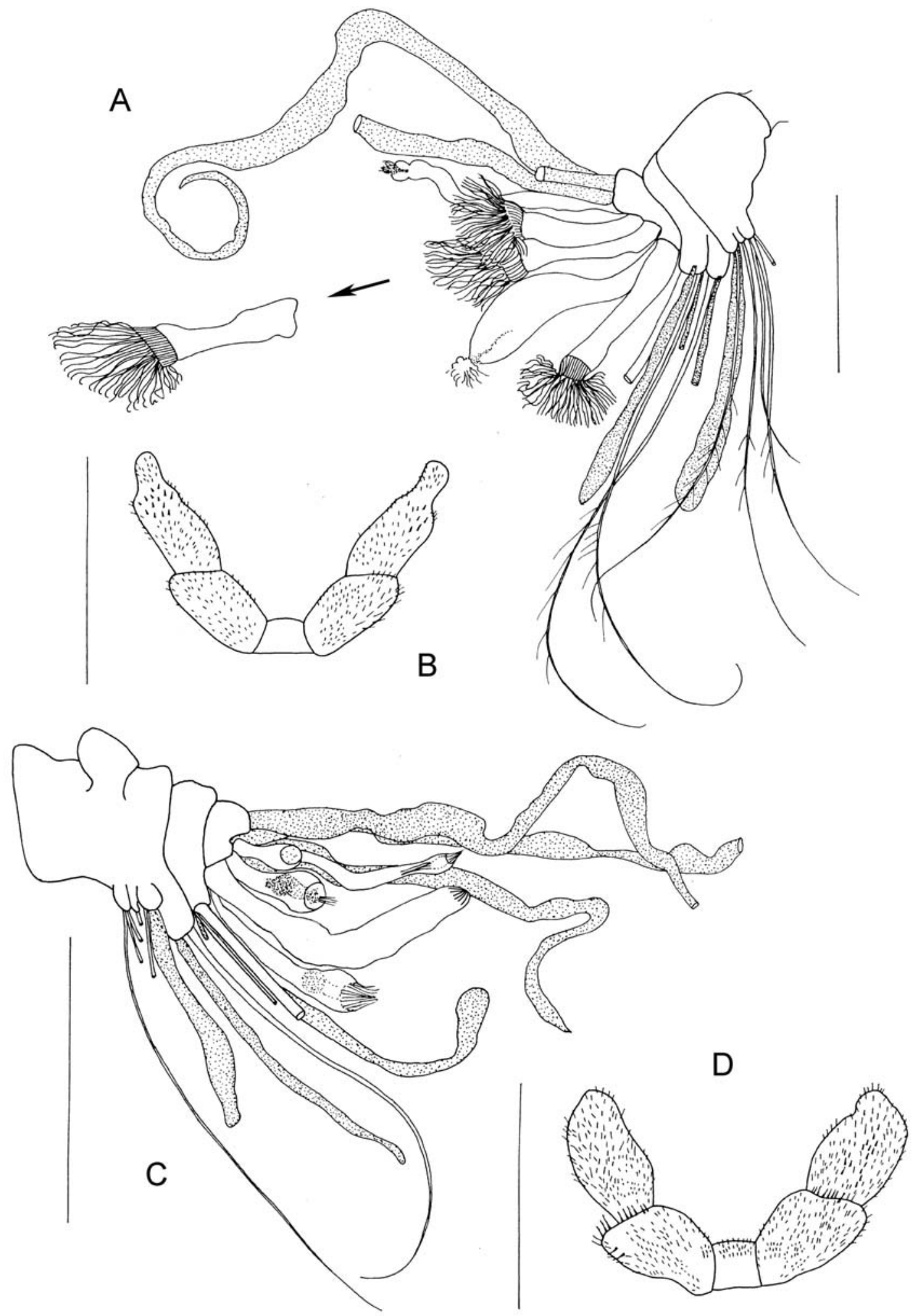

Fig. 4. Diaiscolecithrix andeep gen. et sp.n., female, holotype (A-B), female, copepodite V (C) and Diaiscolecithrix sp., female (D): A - maxilla; B - P5; C - maxilla; D - P5. Scale bars $0.1 \mathrm{~mm}$.

Pис. 4. Diaiscolecithrix andeep gen. et sp.n., самка, голотип (A-B), самка, копеподит V стадии (C) и Diaiscolecithrix sp., самка (В): А — максилла; В - P5; C — максилла; D - Р5. Масштаб 0,1 мм. 

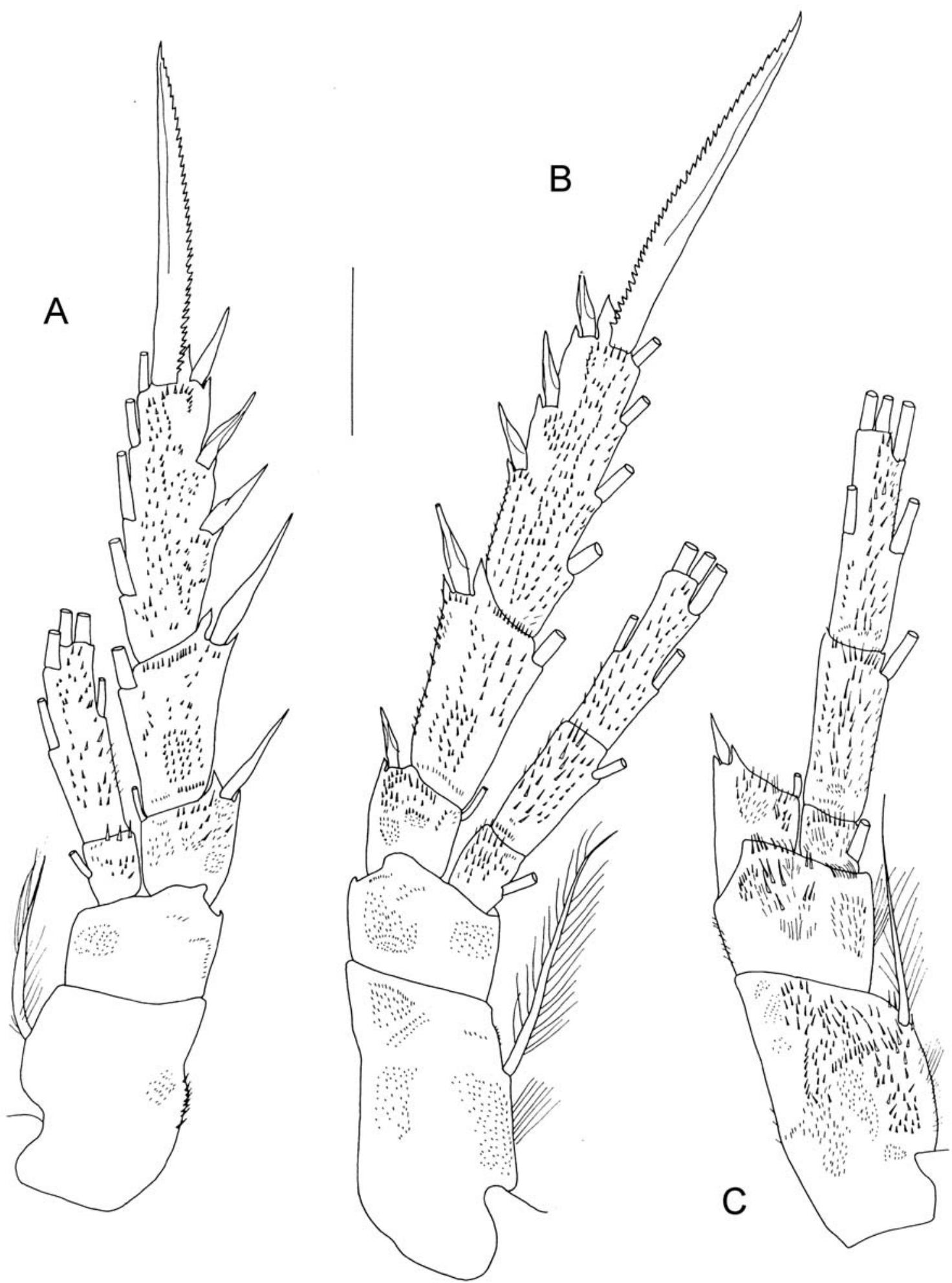

Fig. 5. Diaiscolecithrix andeep gen. et sp.n., female, holotype: A - P2, posterior; B - P3, posterior; C - P4, posterior. Scale bar 0.1 $\mathrm{mm}$.

Рис. 5. Diaiscolecithrix andeep gen. et sp.n., самка, голотип: A - P2, задняя поверхность; В - P3, задняя поверхность; С - P4, задняя поверхность. Масштаб 0,1 мм. 
tails of setal armament of maxillule and a hump on maxilla (Grice \& Hulsemann, 1970: 215, Figs 172190). These authors placed this species in the genus Diaixis; the species, however, does not fit well in the diagnostic characters of this genus and deviates in: i) a derived type of antenna setation as $0,0-0-0,1,1,1,1$, 1,3 (vs. 1, 1-1-1, 1, 1, 1, 1, 0, 3, in Diaixis); ii) maxillule arthrite with 5 setae (vs. 8 setae in Diaixis), iii) basal endite plus endopod of maxillule with 6 setae, 2 of these sensory (vs. 2-4 setae on distal basal endite and 8-10 setae on endopod, but no sensory setae in Diaixis), and iv) 1, 2, 1 sequence of setae on maxilliped praecoxal endites of syncoxa (vs. 1, 2, 3 sequence in Diaixis). Thus, D. asymmetrica appears to be more closely related to Diaiscolecithrix. New findings and a detailed revision of Diaixis asymmetrica in the near future might show that this species has to be transferred to the new genus described in this paper.

ACKNOWLEDGEMENTS. The authors thank Prof. Angelika Brandt for providing the unsorted copepod fraction of ANDEEP-SYSTCO and ANDEEP III, which yielded the specimens described in this paper. Research of E.L. Markhaseva at Deutsches Zentrum fuer Marine Biodiversitaetsforschung (DZMB-Senckenberg, Biozentrum Grindel \& Zoologisches Museum Hamburg) was funded by CeDAMar (Census of the Diversity of Abyssal Marine Life) and supported by grant \# 08-04-00150-a of the Russian Foundation for Basic Research.

\section{References}

Brandt A., Ebbe B., Gooday A.J. 2007. Introduction to ANDEEP, summary and Outlook // Deep-Sea Research II. Vol.54. P.16451651.

Brandt A., Hilbig B. 2004. ANDEEP (Antarctic benthic deep-sea Biodiversity colonization history and recent community patterns) - a tribute to Howard I. Sanders // Deep-Sea Research II. Vol.51. P.1457-1919.

Brenke N. 2005. An epibenthic sledge for operations on marine soft bottom and bedrock // Marine Technology Society Journal // Vol.39. P.10-19.

Grice G.D., Hulsemann K. 1970. New species of bottom-living calanoid copepods collected in deep-water by the DSRV Alvin // Bulletin of the Museum of Comparative Zoology. Vol.139. P.185-230.

Markhaseva E.L., Ferrari F.D. 2005. New benthopelagic bradfordian calanoids Crustacea: Copepoda) from the Pacific Ocean with comments on generic Relationship // Invertebrate Zoology. Vol.2. P.111-168.

Markhaseva E.L., Schulz K. 2007. New species of Brodskius, Rythabis, and Omorius (Crustacea: Calanoida) from deep Antarctic waters // Journal of Natural History. Vol.41. P.731-750.

Markhaseva E.L., Schulz K. 2009. A new family and genus of calanoid copepods (Crustacea) from the abyss of the Atlantic Ocean // Zootaxa. Vol.2304. P.21-40.

Ohtsuka S., Nishida S., Nakaguchi K. 2002. Three new species of the genus Macandrewella (Copepoda: Calanoida: Scolecitrichidae) from the Pacific Ocean, with notes on distribution and feeding habits // Journal of Natural History. Vol.36. P. 531-564.

Schulz K. 2005. A new species of benthopelagic copepods (Crustacea, Calanoida) from the deep Southern Ocean // Mitteilungen aus dem Hamburgischen Zoologischen Museum und Institut. Vol.102. P.51-70. 